\title{
早期胃癌拈よび S 状結腸癌・直腸癌の
}

\section{同時性三重複癌の一根治例}

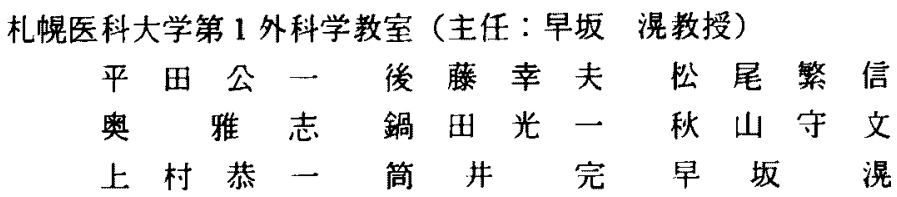

A GASE OF DOUBLE COLONIC (SIGMOID AND RECTUM) CARCINOMAS ASSOCIATED WITH PRIMARY EARLY GASTRIC CANCER -A TREATMENT AND A REVIEW-

Kouichi HIRATA, Yukio GOTO, Shigenobu MATSUO, Masashi OKU, Koichi NABETA, Morifumi AKIYAMA, Kyoichi UEMURA, Tamotsu TSUTSUI and Hiroshi HAYASAKA

Ist Department of Surgery, Sapporo Medical Coilege, Sapporo, Japan, 060

近年, 各種癌の診断, 治療成績の向上ととるに重複癌の発生をみる頻度す增加する傾向 にある. 胃癌症例でる同様な傾向がみられており，重複癌の一方が消化管癌，なかです胃 癌である場合が多い，さらに食生活内容の欧米化に伴い大晹癌発生頻度が年々多くなって いるといわれ，胃・大腸の重複癌症例は向後增加すると思われる．特に胃・大腸の重複癌 の場合は同一系統䑏器であることから向癌性素因が先天的にあるとする内因説が考えやす いし，同一刺激に上るとする外因説にもあてはまる。

著者らは，約 5 年間慢性胃潰瘍で治療をらけていた患者に早期胃癌を発見後，ますなく 鮮血色の下血発生の為, 精查の結果, 直腸および $\mathrm{S}$ 状結腸癌の合併を確認した症例を経験 したので報告する．

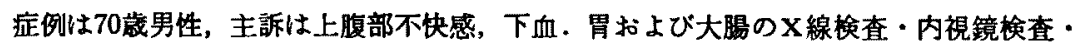
病理組織学的検査で，胃・S 状結腸・直腸の 3 重複癌であることを確認した．1979年12月 14日手術施行，胃癌に対しては二群リンバ節まての遊清と $2 / 3$ 胃切除を行なった。結腸・ 直腸癌に対しては三群リンバ節をでの廊清とマイルス手術を行なった。切除胃病理組織学 的所見で，早期胃癌であることを確認した．さらに廊清したリン八節に，全く転移を認め なかった，衍後は極めて良好で，他睵器に異常を認めず，1980年 3 月 2 日退院し，現在定 期的に外来通院で経過観察中である.

はじめに

診断技術の向上・普及および治㞠成瞔の向上とともに 他瞊器に重複癌発生をみる機会が近年增加しつつあるの は周知のことである.

最近われわれは，I c 型の早期胃癌と原発性 $\mathrm{S}$ 状結腸 癌および直腸癌とが同時に存在した重複癌症例を程験し
たので報告し，重複癌について若干の考察を加える.

症例 : 70筬, 男

主訴：上腹部不快感，下血

家族歴：乳癌 (実妹)

既往歴：47歳時，事故に上り左第 7，8助骨骨折，右 鎖骨骨折，50歳時，肺結核 70歳時急性虫垂资で虫垂切 
除を受ける.

現病歴：1974年夏頃から食後に上腹部不快感が出現し 数度の胃 X線検査之内視鏡検査で慢性胃炎の診断をらけ 制酸剤を服用していた．1979年10月某医における内視鏡 検查の結果胃癌と診断された. その後間もなく鮮血便が 生し，大腸 $\mathrm{X}$ 線検査扰よび大腸内視鏡検査の結果，直腸 癌を合併していることがわかり手術を目的として同年12 月 6 日当科入転科入院となった。

入院時所見 : 体格中等, 栄養良, 眼䀫およひ眼球結膜 に資血および黄疾等の所見を認めず，軍大リンパ節も触 知しない，胸部は理学的に異常所見はない，腹部は平担 で肝脾を触知せず，心富部に軽度の王痛を認めるが，腫 瘤および抵抗を触れない，直腸指診で指尖部に腫瘤を触

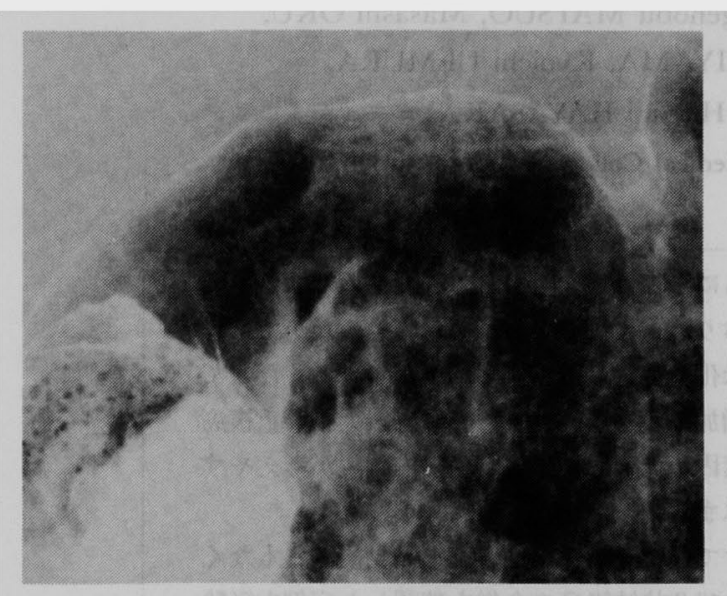

写真1音所見：前庭部後壁大弯㑡寄りに山 凸不整を伴ら浅い陥凹性病变がある。

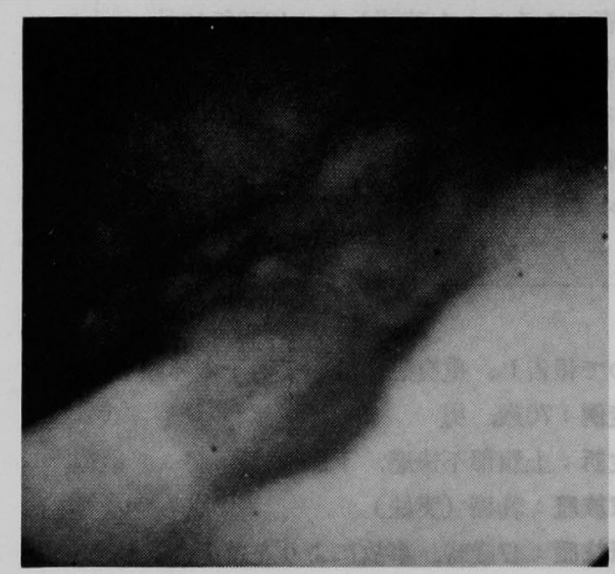

写本 2 内内視鏡所見：II c 倳病変を認める。
れ、この腫瘤は易出血性であった。

臨床换查成縝 : 血色素 $12.9 \mathrm{~g} / \mathrm{dl}$, 赤血球数 421 万, へ了 トクリット39\%で筫血はなかったか，便潜血反応は陽性 であった．CEA 值は， $130 \mathrm{ng} / \mathrm{ml}$ と高値を示した。さ らにリウマチ反応 CRP が陽性である以外に他の血液模 査，尿検查において異常はなかった。

胃 $\mathrm{X}$ 線㭘査では，二重造影像で胃角部の拡大と胃前庭 部に辺縁の不規則な浅い潰掦があり，同部の造影剂の残

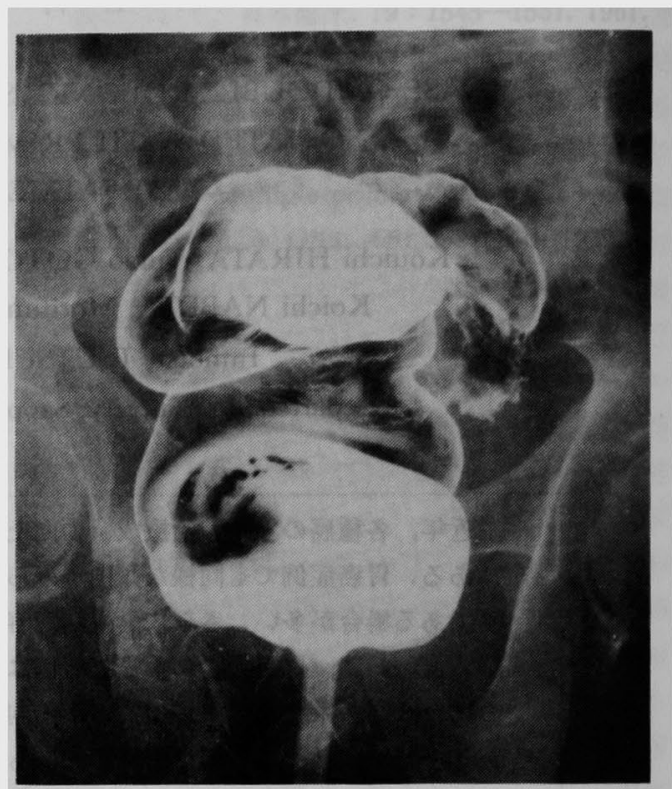

写央 3 注煦 Ba. 所見：直晹に隆起性病変, $\mathrm{S}$ 状 結腸に狭䆨を認める。

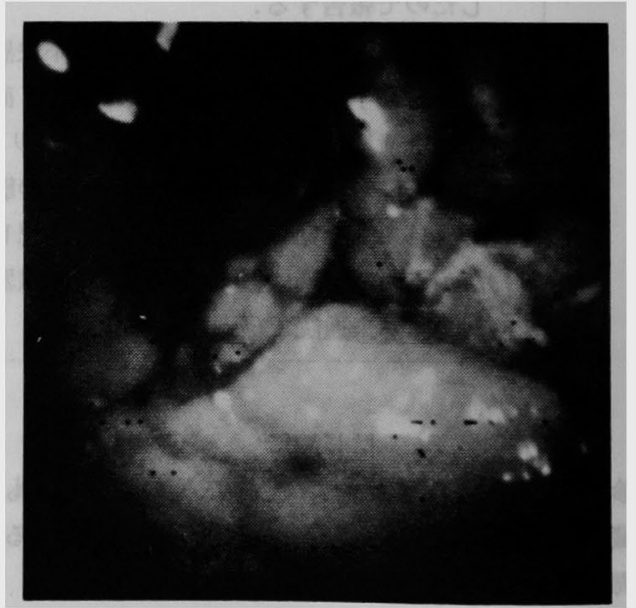

写真 4 直腸部内視鏡所見：不 規則な小隆起を伴 5 Borrmann I 型様病变 
ク方からその洪瘍庭に凹凸不整のあることが推測され， 癌性の陥山性病変と考えられた（写克1）.

胃内視鏡検査では, 胃前庭後壁に辺縁が明瞭な浅い潰 疡があり，その溃曒の周囲粘膜は，萎縮性であった（写 交 2 ). 胃角上部に線状潰㿋があった。

大腸 $\mathrm{x}$ 線検査所見では, Rb 領域に隆起性病変を認め, さらに肛門より $30 \mathrm{~cm}$ の部分で強度の㹟菅があり造影剂 の注入が不能であった（写牙 3 ).

大晹内視鏡恰査では, 肛門より䄪 $8 \mathrm{~cm}$ の部分に Borrmann I 型様の尰瘤 (写真 4), さらに $30 \mathrm{~cm}$ の部位に 狭窄があり,この間の粘膜像は, びらん性変化を生じ, ところどころで出血を伴っていた.

血管造影（腹胿動脈，上腸間膜動脈）および肝シンチ グラムに異常所見を認めなかった.

手術所見：1979年12月14日，胃および S 状結腸，直腸 の同時性重複癌の診断で開腹した，胃癌に対しては型の 如く 2 群りンパ節までの邡清と約 $2 / 3$ 胃切除を行なった。 肉眼的に所属リンパ節に転移を認めず，粠膜面への浸潤 むなかった，同時に下腸間膜動脈根部を結禁し，直腸お よび S 状結腸領域に対する 3 群リンパ節群まで邡清し， Miles 手術を行なった.

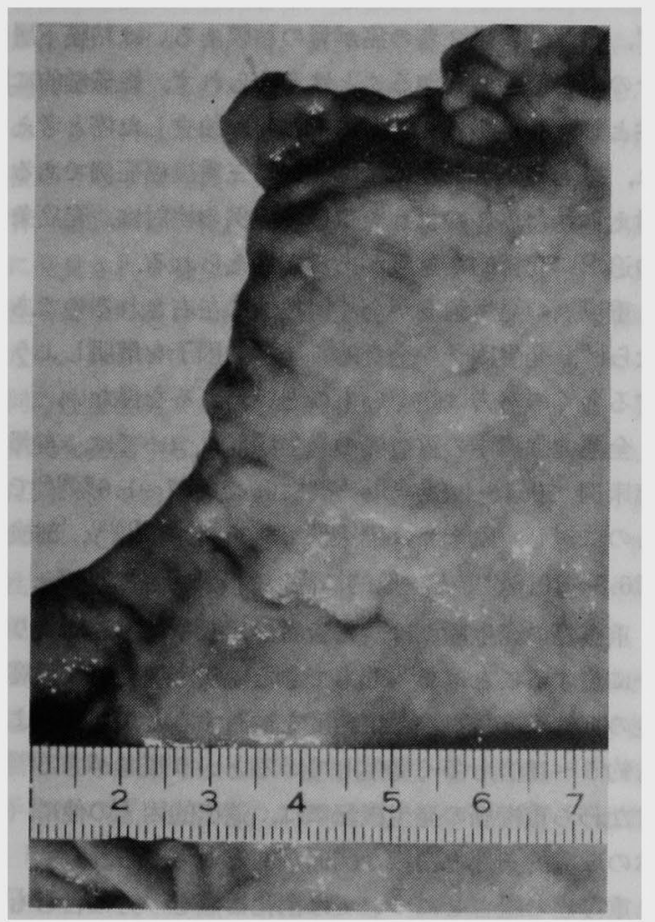

写查 5 a 切除鱼 IIc 䇐病变
$\mathrm{S}$ 状結腸部の腫瘤は，腹膜翻転部で膀胱壁に直接浸潤 し，このため膀脱壁の一部を $\mathrm{S}$ 状結腸癌とともに一塊と して切除した. 肉眼的には，傍 S 状結腸領域のリンパ節 を含め第 3 群リンパ節まで転移を認めなかった。

切除標本の肉眼的所見 : 切除胃では, 胃前庭部後壁寄 りに $1.2 \times 0.8 \mathrm{~cm}$ 大の境界明瞭な II c 様病変があり（写 卉 $5 \mathrm{a}$ ), この陥凹部に長径䄪 $0.5 \mathrm{~cm} と 0.2 \mathrm{~cm}$ 大の島が あった. さらに胃角部前庭寄りに長さ $2.5 \mathrm{~cm}$ の線状潰 痬を伴っていた。

$S$ 状結腸には，ほぼ全周性にわたる6.0 大の Borrmann III型の癌腫があった.この癌腫が腹膜翻 転部の腸管壁に直接浸潤しさらに口側の結腸に瘦性潰湟 が形成されていた。

直腸には， $3.5 \times 3.3 \times 1.5 \mathrm{~cm}$ 大の Borrmann I 型の 癌尰があった（写式 5 b).

\section{病理組境所見}

(1) 切除胃組織診断 (図 1 a)

1) moderately differentiat d tubular adenocarcinoma (CAT II, SAT 2, INF) (sm, ly $\left.\mathrm{y}_{1}, \mathrm{v}_{0}, \mathrm{n}_{1-2}(-)\right)$ (aw $(-)$, ow $(-))$

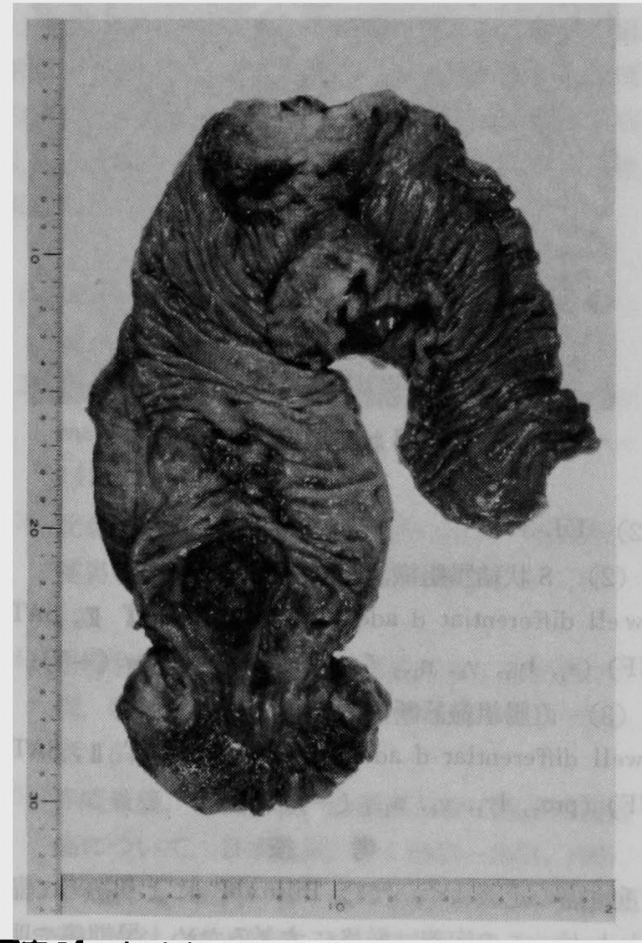

写空 5 b 切除大得所見 : 直腊 $\mathrm{Rb}$ 領域に Borrmann I 型様腫瘤を, S 状結腸で長さ的 $5.5 \mathrm{~cm}$ に渡る 全周性の狭窄を認める。 


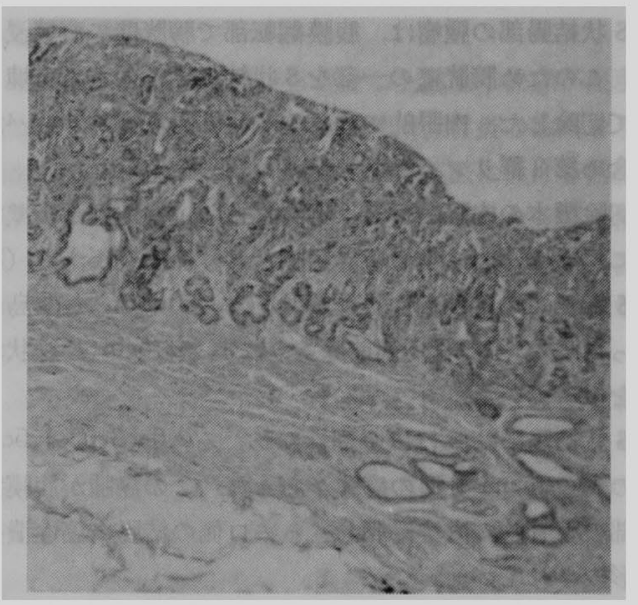

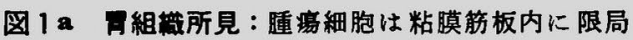
している.

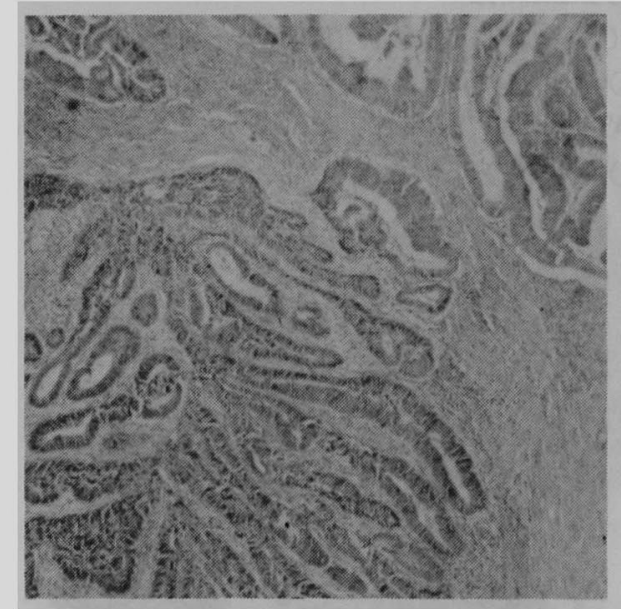

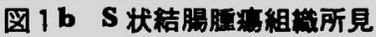

\section{2) UL-3}

（2） S 状結腸組織診断（図 1 b)

well differentiat $\mathbf{d}$ adenocarcinoma (CAT II, SAT 2, INF) $\left(s_{1}, l_{y_{1}}, v_{0}, n_{1-3}(-)\right)$ (aw (-), ow (-))

（3）直腸組織診断 (図 1 c)

well differentiat d adenocarcinoma (CAT II, SAT 2, INF) $\left(\mathrm{pm}_{1}, \mathrm{ly}_{1}, \mathrm{v}_{0}, \mathrm{n}_{1-3}(-)\right)$

$$
\text { 考按 }
$$

重複癌の定義については Billroth" により初めて記載 されたが，この定義は㹈格にすぎるため，早期癌や明ら かな重複癌が除外される可能性が大きかった。 そこで Warren and Gates ${ }^{2)}$ が修正を加文，(1）各腫瘍は一定

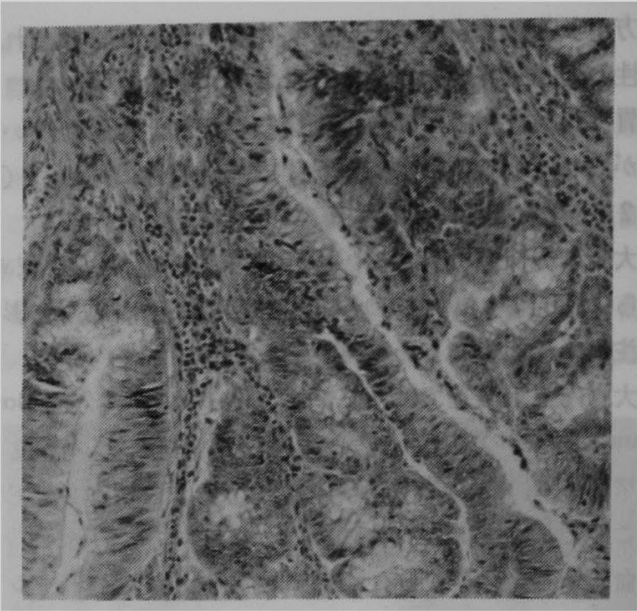

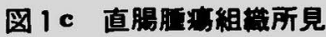

の組織像を有すること，（2）各隀烜は互いに離れた部

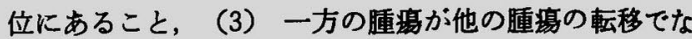
いことを証明すること，の条件を満足させることを今日 の定義としている.

本症例は，胃癌が粘膜下層までの早期癌で所属リンパ 節へ転移はなく，従って既に進行癌の様相を呈していた $\mathrm{S}$ 状結腸癌および直腸癌の胃壁への転移とは考えられ ず，また逆に後 2 者の癌が胃の粘膜あるいは粘膜下層部 分のみへ転移巣を作ることは考えられず，組織学的に歴 然とした違いが無くとも，それぞれ独立した癌と考えら れ，以上のような理由で本症例は三重複癌症例であると 考えられた.このよらな重複癌症例の検討は, 発癌条件 の追求に究極的な意義があると考えられる.

重複癌の発生頻度が全く偶然性に左右されるのである ならば，発生因子の全身的，局所的因子を解明しようと する多くの努力は空しいるのといわざるを得ない.

全悪性腫湯中の重蕧癌の発生頻度については, 本邦の

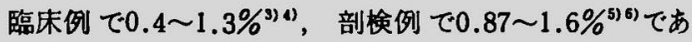

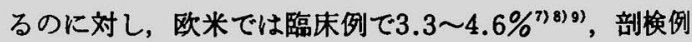
で6.8 10.6 ${ }^{2) 9)}$ と一般的に高い数值を示している.

重複癌の発生頻度は, 報告者の定義や症例数により同 一に論ずることは必ずしもできないが，偶発的な両癌発 生の期待値と重複癌発生頻度を検討すると, 期待値より も約 $5 \sim 15$ 倍む多く発生しているとい5傾向がある ${ }^{2) 3}$. すなわち重複癌の発生機転には，遣层的因子の他に，個 体の環境的条件と密接な関係があると考えられる.

重複密の組合せについては消化器癌を一方に含むるの が多いといわれ，その中でも特に胃癌が多いとされてい 


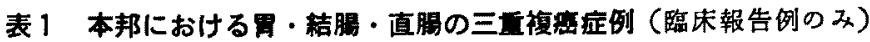

\begin{tabular}{|c|c|c|c|c|c|c|c|c|}
\hline No. & 報告者 & 年度 & 症例 & 発生時期 & 周 & 結 & 直 腸 & 予後 \\
\hline 1 & 大山 ${ }^{131}$ & 1972 & $37 \delta$ & 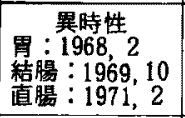 & $\begin{array}{c}\text { I } \mathrm{c} \\
\left.\text { (tub, sm, } \mathrm{n}_{2}(-)\right)\end{array}$ & 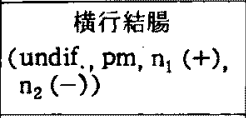 & $\left(\right.$ pap, sm, $\left.\mathrm{n}_{2}(-)\right)$ & 生存 \\
\hline 2 & 遠藤 ${ }^{4}$ & 1972 & $72 \delta$ & 同時性 & $\left(\mathrm{tub}_{2}, \mathrm{pm}, \mathrm{n} ?\right)$ & $\begin{array}{c}\mathrm{S} \text { 状結腸 } \\
(\mathrm{tub}, \mathrm{pm}, \mathrm{n} ?)\end{array}$ & (tub, $\mathrm{pm}, \mathrm{n}$ ?) & $\begin{array}{c}\text { 生存 } \\
(7 \text { カ月) } \\
\end{array}$ \\
\hline 3 & 自験例 & 1980 & 708 & 同時性 & $\begin{array}{c}\text { II } c \\
\left(\text { tub }_{2}, \sin , \mathrm{n}_{1-2}(-)\right)\end{array}$ & $\begin{array}{l}\text { S状結腸 } \\
\left(\begin{array}{l}\text { well dif., } \\
(-))\end{array}\right.\end{array}$ & $\underset{\left.n_{1-3}(-)\right)}{(\text { well dif }}, \mathrm{pm}_{1}$, & 生存 \\
\hline
\end{tabular}

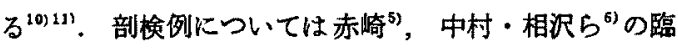

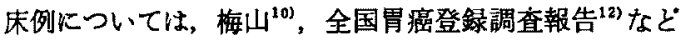
の詳細な報告がある、これらの報告によると胃癌に対す る一方の癌は，剖検例で肺癌，食道癌，子宮癌，甲状腺 癌の順であるのに対し，臨床例では梅山(10)らによると食 道癌，腸癌，乳癌の順であり，胃癌研究会と国立がん七 ンターによる全国胃癌登録調查報告 ${ }^{12)}$ では，直腸癌，肝 癌，食道癌，経腸癌，乳癌の順である.

著者らが調べた範囲では1967年から1979年までの13年 間に，胃と結腸の重複癌報告例は40例，胃と直腸の重複 䙖は12例であるが，全国胃癌登録調查報告 ${ }^{12)}$ によると19 63年から1970年の 8 年間に，胃と直腸の重複癌51例，胃 と結腸の重複癌は34例あり，報告例よりるかなり多い数 值が出ている. 一方, 胃, 結腸 直腸の三重複癌報告例 は過去に 2 例あるのみで(2)16)，本症例は3 例目である. このらち 1 例は本正例と同 $\mathrm{L}$ 胃， $\mathrm{S}$ 状結腸，直腸同時性 重複癌であった（表 1 )。

胃，結腸および胃，直腸の重複癌症例については同時 性に発見される場合が多い: ${ }^{15)}$ ：この同時性あるいは，異 時性の基準に関しては，報告者により異なり一定の基準 がない.Peller ${ }^{16)}$ は，真に同時期に証明された症例のみ が同時性重複癌であると主張してはいるものの, 癌 発 育期間を推測すると一年以内に証明さ执た重複癌につい ては同時性であると考えた方が良いとしている.この基 準に従って梅山衫らは重複癌症例を検討したところ, 同 時性重複癌と異時性重複癌の発生頻度は，2：1で性别 に差はないとのべている。

本症例のよ5に重複癌の一方が早期癌である症例報告

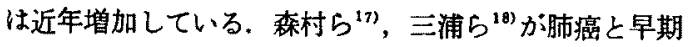
胃癌の同時合併例を，異時性重複癌として伊藤ら ${ }^{191}$ が胃

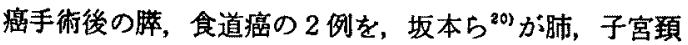
部，咽頭部，食道癌の 3 例を報告している.

早期胃癌と大腸癌の報告例は, 上行結腸癌 ${ }^{(1) 21) 2]} 4$ 例， $\mathrm{S}$ 状経腸癌 2 例 $^{23)}$ ，横行結腸癌 1 例，下行結腸癌 1
例, 直腸癌 1 (例 ${ }^{22)}$ である. 前二者の 2 例のうら各々 1 例 は同時性であった。

今後は胃のみならず，大腸早期癌の発見の機会む増古 るであろらし，消化器以外の重複癌を合併することも増 えることと思われる，今日，癌の保存的療法にある程度 の限界がある以上，担癌生体に対しては一搭器のみに目 を集中させることなく，絶えず全身症状に注目し，追跡 調査を行なら必要がある.

$$
\text { まとめ }
$$

早期胃癌の診断直後，下血を訴え精査の結果， $\mathrm{S}$ 状 結腸に同時に癌が存在した70藏男性に，胃癌根治手術 $\left(R_{2}\right)$ と Miles 手術 $\left(R_{3}\right)$ を同時に施行し, 術後の組織 学的検索の結果, 三重複癌であるとの診断を得た症例を 報告するとともに，重複癌について若干の文献的考察を 加えた。（本論文の要旨は日臨外北海道支部第37回総会 で報告した。)

\section{参考文献}

1) Billroth, T.: Chirurgische Klinik, Wien., Berlin, p. 258, 1879.

2) Warren, S. and Gates, O.: Multiple primary malignant tumors. Am. J. Cancer, 16: 13581414, 1932.

3) 北皇 隆, 金子昌生, 木戸長一郎地：重複悪性 腫瘍の発生頻度に関して, 癌の臨床, $6: 337$ $345,1960$.

4) 岩崎利通, 安達秀婎, 山内義正他：重複癌の 6 例，特に直腸と堅の重複癌例儿ついて，外科， $33: 646-651,1971$.

5）赤崎兼義，若狭治毅，石館卓三他：原発性重複 癌について。 日本臨床, $19: 1543-1551,1961$,

6) 中村恭二, 相沢 幹: 組み合わせよりみた重複 癌の検討. 癌の臨床, 18：662-666, 1972.

7) Hurt, H.H.: Multiple primary malignant neoplasms. J. Lab. Clin. Med., 18: 765-777, 
1933.

8) Moertel, C.G.: Multiple primary malignant neoplasms. I. Introduction and presentation of data. Cancer, 14: 221-230, 1961.

9) Moertel, C.G.: Multiple primary malignant neoplasms. II. Tumors of different tissues or organes. Cancer, 14: 231-237, 1961.

10）梅山繁，湏加野誠治，兽和䖵生他：過去10年 間における本邦重複癌症例の文献的考察, 日本 臨休, $32: 587-595,1974$.

11) 岸本宏之, 奥 英敏, 杉原登司夫他 : 胃癌之他 重复癌との重愎例について, 癌の踟床, 23 : $550-556,1977$.

12）胃がん研究会・国立がんセンター：全国胃がん 登録調查報告，第 1 号一第 6 号.

13）大山満, 長野稔一, 阿久根務他 : 大腸重複癌 と早期胃癌を認めた 1 症例, 癌の臨床, 18 : $826-830,1972$.

14) 遠藤権三郎, 和田達雄, 五島英妯他: 消化器重 複癌の手術，日消外会誌，5:209-210，1972.

15）飯塚益生，木村信良，入度信広他：胃・横行 経晹同時性重褐癌の1例, 日臨外会誌, 36 : 184-189, 1975.

16) Pellers, S.: Metachronous multiple malig- nancies in 5876 cancer patients. Am. J. Hygine, 34: 1-7, 1941.

17）森村義行, 渡辺幸司, 中村能史地：原発性重裉

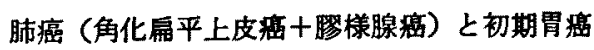
のみられた一剖検例. 日本漓学会総会記事. $26: 284,1967$.

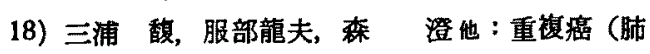

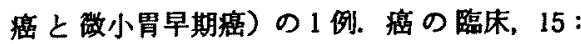
$801-804,1969$.

19）伊藤一三，渡辺 弘，三陯 他 : 早期胃癌再 発例の検討. 日外会誌, $70: 1090-1091,1961$.

20）坂本啓介, 秋山 洋, 标原境他: 早期胃癌手 術例に発生した異種䐵器重被癌の3例（内 1 例 は 3 重複癌）について，外科診療，12：1513一 $1518,1970$.

21）岩崎有良, 高橋 淳, 奥泉 綮他: 結腸瘦を併 存した多発早期胃癌の 1 例，胃と腸， $7: 369-$ $374,1972$.

22）雨宮嫃二, 大井田二郎, 橋本俊明他 : 胃 - 大腸 重複癌の 2 例, 高知界立中央病院医学雑誌, 5 : $35-42,1978$.

23）森勢伊，河辺光国，岩本吉雄他：胃結腸重複 癌の一剖検例，医療，24:491-495，1970. 